\title{
Anthropogenic radioactivity in the Arctic Ocean - review of the results from the joint German project
}

\author{
H. Nies ${ }^{\text {a,* }}$, I.H. Harms ${ }^{\text {b }}$, M.J. Karcher ${ }^{\mathrm{a}, 1}$, D. Dethleff ${ }^{\mathrm{c}}$, C. Bahe ${ }^{\mathrm{a}}$ \\ ${ }^{\text {a } B u n d e s a m t ~ f u ̈ r ~ S e e s c h i f f a h r t ~ u n d ~ H y d r o g r a p h i e, ~ D-20305 ~ H a m b u r g, ~ G e r m a n y ~}$ \\ ${ }^{\mathrm{b}}$ Institut für Meereskunde, Universität Hamburg, Troplowitzstr. 7, D-22529 Hamburg, Germany \\ ${ }^{\mathrm{c}}$ GEOMAR Research Center for Marine Geosciences, Universität Kiel, D-24148 Kiel, Germany
}

\begin{abstract}
The paper presents the results of the joint project carried out in Germany in order to assess the consequences in the marine environment from the dumping of nuclear wastes in the Kara and Barents Seas. The project consisted of experimental work on measurements of radionuclides in samples from the Arctic marine environment and numerical modelling of the potential pathways and dispersion of contaminants in the Arctic Ocean. Water and sediment samples were collected for determination of radionuclide such as ${ }^{137} \mathrm{Cs},{ }^{90} \mathrm{Sr},{ }^{239+}{ }^{240} \mathrm{Pu},{ }^{238} \mathrm{Pu}$, and ${ }^{241} \mathrm{Am}$ and various organic micropollutants. In addition, a few water and numerous surface sediment samples collected in the Kara Sea and from the Kola peninsula were taken by Russian colleagues and analysed for artificial radionuclides by the BSH laboratory. The role of transport by sea ice from the Kara Sea into the Arctic Ocean was assessed by a small subgroup at GEOMAR. This transport process might be considered as a rapid contribution due to entrainment of contaminated sediments into sea ice, following export from the Kara Sea into the transpolar ice drift and subsequent release in the Atlantic Ocean in the area of the East Greenland Current. Numerical modelling of dispersion of pollutants from the Kara and Barents Seas was carried out both on a local scale for the Barents and Kara Seas and for long range dispersion into the Arctic and Atlantic Oceans. Three-dimensional baroclinic circulation models were applied to trace the transport of pollutants. Experimental results were used to validate the model results such as the discharges from the nuclear reprocessing plant at Sellafield and subsequent contamination of the North Sea up the Arctic Seas. (c) 1999 Elsevier Science B.V. All rights reserved.
\end{abstract}

Keywords: Radionuclides; ${ }^{137} \mathrm{Cs} ;{ }^{90} \mathrm{Sr}$; Plutonium; Arctic Ocean

\footnotetext{
* Corresponding author.

${ }^{1}$ Present address: Alfred-Wegener-Institut für Polar- und Meeresforschung (AWI), D-27568 Bremerhaven, Germany.
} 


\section{Introduction}

In 1994, a German project was initiated in order to investigate the transport and dispersion of artificial radioactivity in the Arctic Ocean. The project was realised in close co-operation between the BSH, IfM-Hamburg and GEOMAR, Kiel, as well as in co-operation with Russian Institutes. It was the intention of the project to contribute to international programmes dealing with the environmental consequences of radioactive waste dumped in Arctic Shelf Seas. Part of the numerical model results contributed to the International Arctic Seas Assessment Program (IASAP) (Sjoeblom and Linsley, 1998), in particular to the Modelling Task Group (Povinec et al., 1997; Scott et al., 1998; Baxter et al., 1998).

Two modelling groups studied circulation and transport processes in the Arctic Ocean and Arctic Shelf Seas (Barents and Kara Sea) using numerical, hydrodynamic ice-ocean models on different scales. Additionally, empirical field work was carried out which included the investigation of radionuclide concentrations in water and sediment of the Nordic Seas and Arctic Ocean. In order to evaluate the role of sea ice in the large scale distribution of particle-bound radionuclides, a sedimentological group at GEOMAR investigated potential hydrodynamic and cryological mechanisms of material resuspension, entrainment into Arctic sea ice, and subsequent dispersal from the Kara Sea.

\subsection{The Arctic Ocean circulation}

The stratification of the Arctic Ocean is dominated by the 'halocline', a transition zone that separates cold and fresh surface waters from warmer and more saline intermediate waters. Similarly, the Arctic Ocean circulation can be separated into a surface regime above the halocline and an intermediate regime below.

At the surface, the general circulation of the Arctic Ocean is dominated by the Beaufort Gyre and the Transpolar Drift (TPD). These major large-scale features (Coachman and Barnes, 1961) constitute the most effective transport routes for dissolved contaminants in the surface mixed layer.
The largest exchange of volume to or from other oceans is through the Fram Strait: While in the eastern parts cold and fresh polar water (PW) leaves the Arctic with the East Greenland Current (EGC), in the western Fram Strait warm and saline water of Atlantic origin enters with the Westspitsbergen Current (WSC), a continuation of the Norwegian Atlantic Current (NAC). A second branch of Atlantic water enters the Arctic via the Barents Shelf.

In intermediate and deep layers of the Arctic Ocean, the circulation is much slower and more complex than at the surface. Water masses that enter with the WSC turn east and continue below polar surface waters (Rudels et al., 1996), forming the core of an Atlantic layer which lies at approximately 200-600 m depth. This water re-circulates in several cyclonic loops along the major ridges and slopes in the Eurasian and Canadian Basins to exit finally also through Fram Strait below the PW (Rudels et al., 1994).

\subsection{Arctic shelf seas}

The two most important Arctic shelf areas in this context are the Barents Sea as an important exchange region between north Atlantic and Arctic, and the Kara Sea. The Barents Sea is a throughflow region for Atlantic water masses and the Norwegian Coastal Current (NCC) on their way towards the central Arctic. The main current systems in the Barents Sea are remarkably stable and do not show intense seasonal variability (Ådlandsvik and Loeng, 1991; Harms, 1997a).

In contrast to the Barents Sea, the Kara Sea can be regarded as a semi-enclosed basin. In the south-western parts, water of Atlantic origin and water from the NCC prevail due to the inflow through the Kara Strait. The main difference to the Barents Sea arises from the large freshwater run-off in spring which influences almost the entire Kara Sea. Freshwater supply to the Kara Sea is mainly through the rivers $\mathrm{Ob}$ and Yenisei. The wind has a pronounced seasonal cycle, being strong in winter from south to south-west and weak in summer from north to north-east. Therefore, a strong seasonal variability in simulated current patterns and hydrography prevails (Harms 
and Karcher, 1998). Dense water formation in significant quantities as in the Barents Sea does not take place in the Kara Sea. The two main outflow directions are eastward into the Laptev Sea and northward where Kara Sea water masses join the TPD in the central Arctic Ocean.

\subsection{Sea ice drift}

During the last few years, several publications addressed the importance of long range sediment transport by sea ice in the Arctic [overview given by Nürnberg et al. (1994)]. Considerable amounts of sediment or particulate material is transported from shallow Siberian Shelves towards the Fram Strait (e.g. Dethleff et al., 1994; Eicken et al., 1997). Through ice melting, the material is released to the marine environment of the Nordic seas. The transport of particulate material by sea ice may therefore play an important role in the long-range redistribution of radionuclides in the Arctic and north Atlantic (Pfirman et al., 1997).

Ice movement in the Arctic Ocean is dominated by the transpolar drift (TPD) and the Beaufort Gyre. The TPD is fed by large ice production areas located in the East Siberian, Kara and Laptev Seas. The TPD is responsible for the major ice export out of the Arctic Ocean via Fram Strait.

\section{Results}

\subsection{Sources of anthropogenic radioactivity}

The sources for radioactivity in the Arctic and in the northern Atlantic are:

- Atmospheric fallout from nuclear weapons testing. The total direct fallout into the Arctic marine environment up to 1993 corresponds to $15 \mathrm{PBq}{ }^{137} \mathrm{Cs}$ (MacDonald and Bewers, 1996).

- Discharges from the reprocessing plants at Sellafield, La Hague and Dounreay. The cumulative and decay corrected total ${ }^{137} \mathrm{Cs}$ radioactivity released in Sellafield amounts to approx. $30 \mathrm{PBq}, 14 \mathrm{PBq}$ of which entered the Arctic regions (Kershaw and Baxter, 1995). Maximum releases from Sellafield occurred in 1975. Releases of ${ }^{137} \mathrm{Cs}$ have been continually reduced since that time.

- The Chernobyl accident. Approximately 100 $\mathrm{PBq}{ }^{137} \mathrm{Cs}$ were released to the atmosphere. Approximately $1 \mathrm{PBq}$ was deposited directly over Arctic regions $\left(70^{\circ}-90^{\circ} \mathrm{N}\right)$. Another $5 \mathrm{PBq}$ was added through marine transport from the Baltic Sea and North Sea via the NCC (Macdonald and Bewers, 1996).

- Dumped radioactive wastes in the Kara and Barents Seas (Yablokov et al., 1993). The dumped objects in the Kara Sea mainly include 17 nuclear ship reactors, seven of them still containing spent fuel. The total radioactive inventory at the time of dumping was 37 PBq. It decayed until 1994 to approximately 4.7 PBq. The dominant nuclides are ${ }^{90} \mathrm{Sr}$, ${ }^{137} \mathrm{Cs},{ }^{63} \mathrm{Ni}$ and ${ }^{241} \mathrm{Pu}$. The amount of ${ }^{137} \mathrm{Cs}$ is estimated to be approximately $1 \mathrm{PBq}$ for 1994 (IAEA, 1997).

- The sunken nuclear submarine 'Komsomolets' south-west of Bear Island in the Norwegian Sea. The wreck containing one nuclear reactor with an estimated inventory of approximately $1.5 \mathrm{PBq}{ }^{90} \mathrm{Sr}$ and $2.0 \mathrm{PBq}{ }^{137} \mathrm{Cs}$ and two torpedoes with nuclear warheads amounting to approximately $6.9 \mathrm{~kg}{ }^{239} \mathrm{Pu}$ corresponding to approximately $16 \mathrm{TBq}$ is located in 1680-m depth (Yablokov et al., 1993; JNREG, 1996; Høibråten et al., 1997).

Other sources of radioactivity in the Arctic, such as Siberian river discharge, nuclear power plants, land bases for nuclear powered vessels and underwater or underground nuclear explosions, are small and of minor importance, in the present context.

\subsection{Levels of anthropogenic radionuclides in the Arctic seas}

Experimental field work was carried out during the cruise with R/V GAUSS in summer 1995 in order to trace Sellafield derived radionuclides in the north, Norwegian, Barents and Greenland seas. The cruise track of $\mathrm{R} / \mathrm{V}$ GAUSS followed 
the well-known transport pattern of contaminated water from the North Sea to Arctic areas and the potential export of water from the Arctic Ocean into the north Atlantic along the East Greenland Current system (Dahlgaard, 1994). During the cruise, water samples were collected, some of them in vertical profiles, and analysed for ${ }^{137} \mathrm{Cs}$, ${ }^{134} \mathrm{Cs}$, partly for ${ }^{90} \mathrm{Sr}$ and tritium, and transuranic nuclides, such as ${ }^{239,240} \mathrm{Pu},{ }^{238} \mathrm{Pu}$ and ${ }^{241} \mathrm{Am}$. In most cases the concentrations of man-made radionuclides and organic contaminants are highest in the North Sea. The Sellafield signal of ${ }^{137} \mathrm{Cs}$ dominating the contamination in former years in the North Sea and adjacent sea areas decreased significantly also in the Barents and Greenland Sea.

Water samples taken in the North Sea (Fig. 1a) showed varying ${ }^{137} \mathrm{Cs}$ activities between 2.5 and $25.5 \mathrm{~Bq} / \mathrm{m}^{3}$. The main contamination sources are discharges from the Sellafield reprocessing plant (UK) into the Irish Sea and outflowing water from the Baltic Sea which was contaminated by the Chernobyl fallout in 1986. The maximum activity near the Orkney Islands was $13.1 \mathrm{~Bq} / \mathrm{m}^{3}$. Following the transport pattern of the prevailing current system through the North Sea, the activity decreased to values near $6 \mathrm{~Bq} / \mathrm{m}^{3}$ in the Skagerrak. The contamination by ${ }^{137} \mathrm{Cs}$ due to discharges from Sellafield and La Hague has decreased significantly in recent years. In 1979, e.g. the detected maximum activity in the North Sea was above $400 \mathrm{~Bq} / \mathrm{m}^{3}$ near the Scottish coast, decreasing subsequently due to discharges from Sellafield.

Concentrations in the Skagerrak (Fig. 1a) region are higher due to continuous outflow from the Baltic Sea, where the Chernobyl contribution is the dominant source. This can be proved by the ${ }^{134} \mathrm{Cs}$ activities detected (activity ratios ${ }^{134} \mathrm{Cs} /{ }^{137} \mathrm{Cs}=0.024-0.040$; expected ratio 1995:0.05) (HELCOM, 1995). The levels of ${ }^{137} \mathrm{Cs}$ in western Baltic surface waters are still between 50 and $100 \mathrm{~Bq} / \mathrm{m}^{3}$.

Water samples near the Norwegian coast (Fig. 1a) showed slightly increased ${ }^{137} \mathrm{Cs}$ activities decreasing in a northerly direction, reflecting the water mass transport $\left(9.6-3.8 \mathrm{~Bq} / \mathrm{m}^{3}\right)$. The sources of these activities are both discharges from Sellafield and contaminated sea water from the Baltic Sea.

The present 'background' concentration in surface water in the northern hemisphere originating from global weapons test fallout during the 1950s and $1960 \mathrm{~s}$ is estimated at $2 \mathrm{~Bq} / \mathrm{m}^{3}{ }^{137} \mathrm{Cs}$. Activities in the Greenland and Norwegian Seas are also low $\left(2.2-4.9 \mathrm{~Bq} / \mathrm{m}^{3}\right)$. The values decrease in deep water layers in the Nordic sea basins, below 1000 $\mathrm{m}\left(2.5-0.8 \mathrm{~Bq} / \mathrm{m}^{3}\right)$ (Fig. 1b). The observed concentrations in the Barents Sea (Fig. 1c) are in this range or slightly above $\left(2.1-3.8 \mathrm{~Bq} / \mathrm{m}^{3}\right)$. Surface and bottom waters (maximum $350 \mathrm{~m}$ depth) in the Barents Sea show no significant differences of contamination in vertical profiles. Somewhat higher values $\left(4.2-4.5 \mathrm{~Bq} / \mathrm{m}^{3}\right)$ are detected in surface waters of the Norwegian Coastal Current, north of northern Norway and near the Kola peninsula (Fig. 1c).

The concentrations of $\mathrm{Pu}$-isotopes measured in seawater profiles have been reported and discussed by Herrmann et al. (1998). A long range transport of Sellafield derived $\mathrm{Pu}$ isotopes to deeper layers in the Greenland Sea was detected by means of the activity ratios ${ }^{238} \mathrm{Pu} /{ }^{239,240} \mathrm{Pu}$.

The activity ratio of ${ }^{137} \mathrm{Cs} /{ }^{90} \mathrm{Sr}$ can be used to identify the source of contamination. Typical ratios of the former Sellafield discharges were significantly above 3.0 before 1985 and in the years 1989-1992 (MAFF, 1995; OSPARCOM, 1997). The ratio from global weapons fallout in open oceanic water is approximately 1.5 (UNSCEAR, 1982). The ratios along the Norwegian coastal current are approximately $2.0-2.1$, while the values in the central part further off the Norwegian coast are lower than 2.0, indicating that this sea area is mainly contaminated by global fallout. The ratios in the Barents Sea are approximately 2.2 which shows that the main contamination sources are both the Sellafield plant and global fallout. Compared to earlier data, the Sellafield signal decreased significantly also in this sea area (Guegueniat et al., 1997; Kershaw et al., 1997). However, in this case a certain contribution by the remnants from the Chernobyl accident can also be assumed. The ${ }^{137} \mathrm{Cs} /{ }^{90} \mathrm{Sr}$ activity ratios in the Greenland Sea are above 2.3 indicating that they are influenced by earlier Sellafield dis- 
charges, where the ratios were above 5.9, before 1985. They rose as high as 11.3 in 1976. The influence of the La Hague discharges before 1985 is expected to be low because they were at least

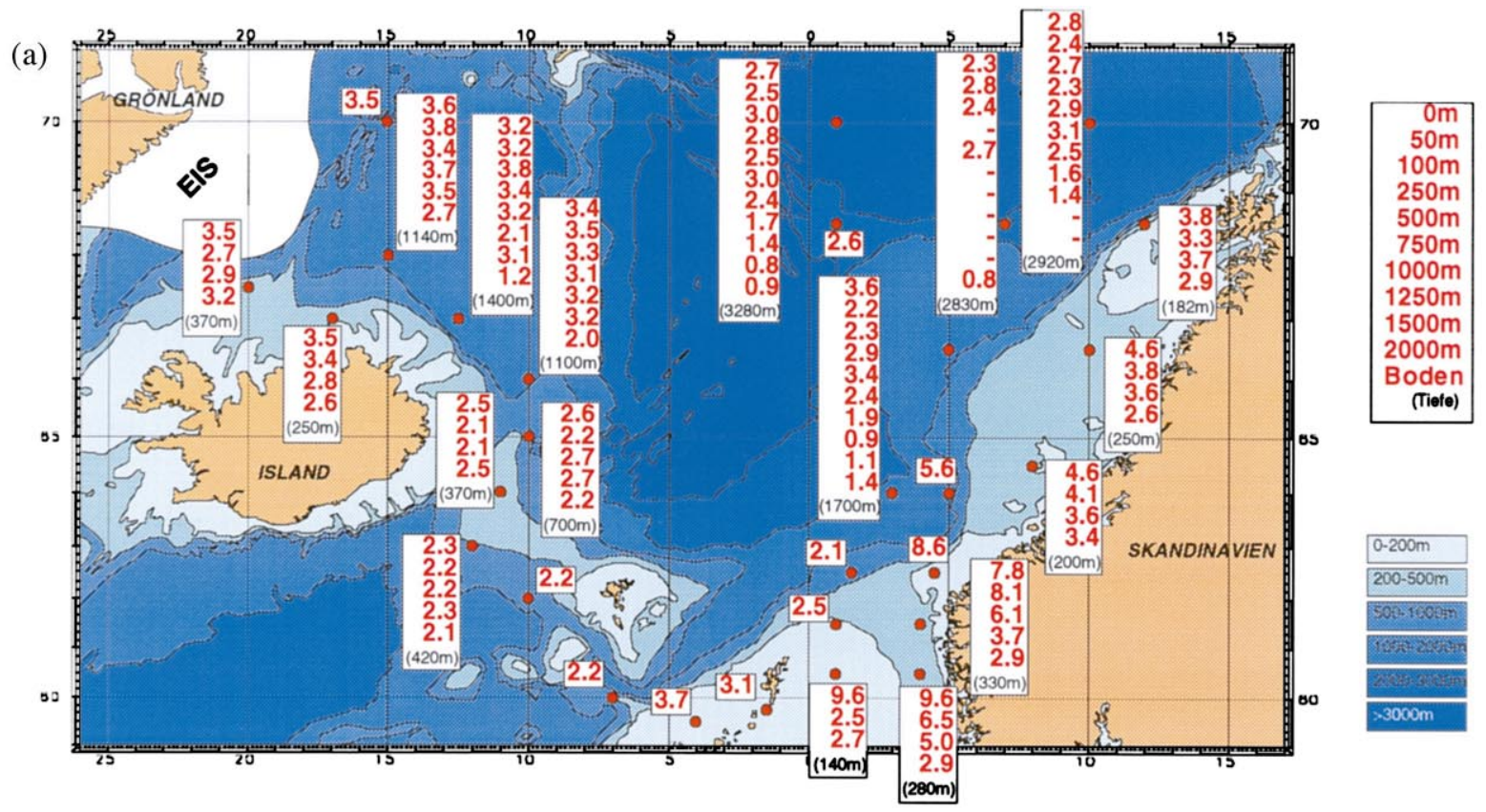

(b)

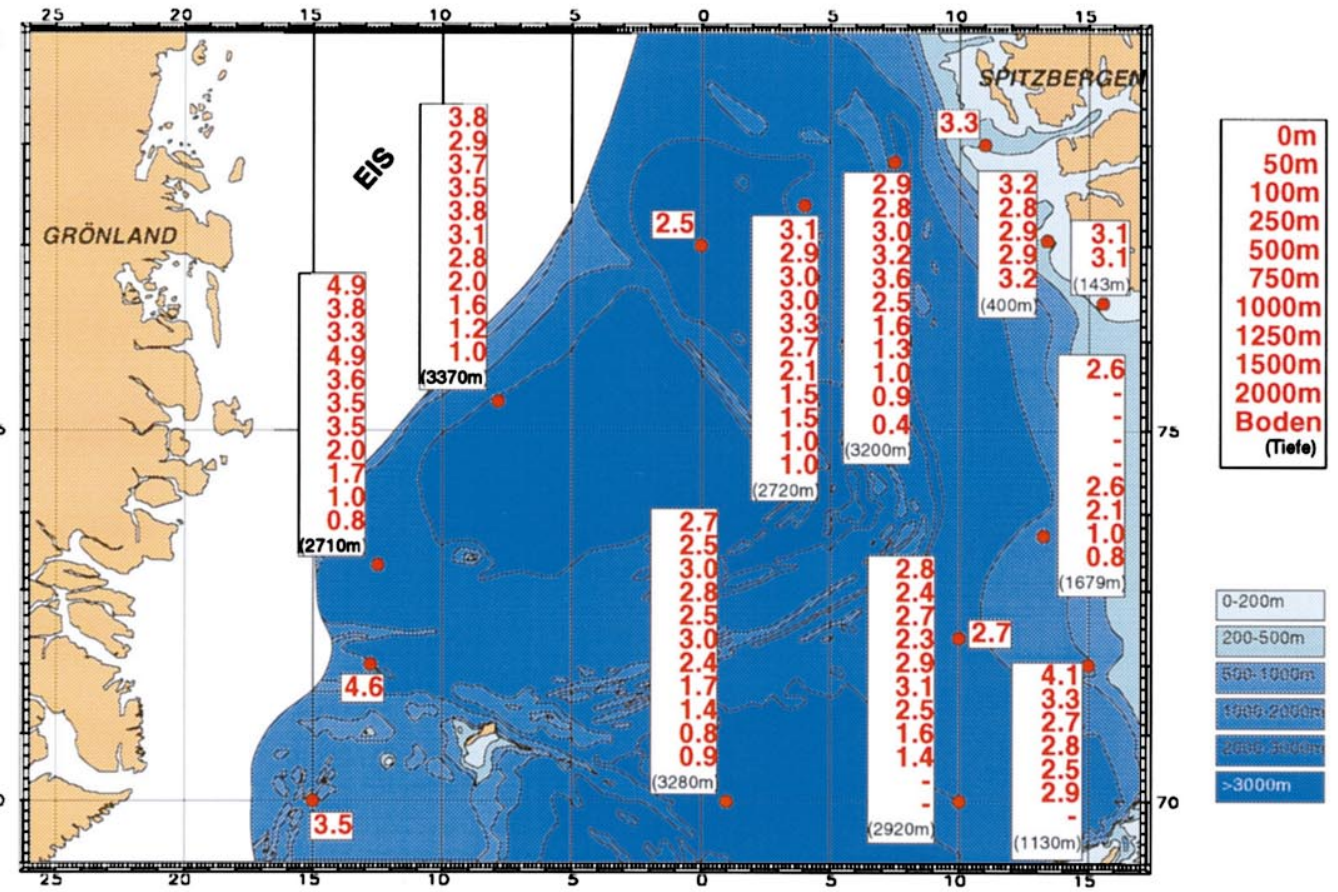




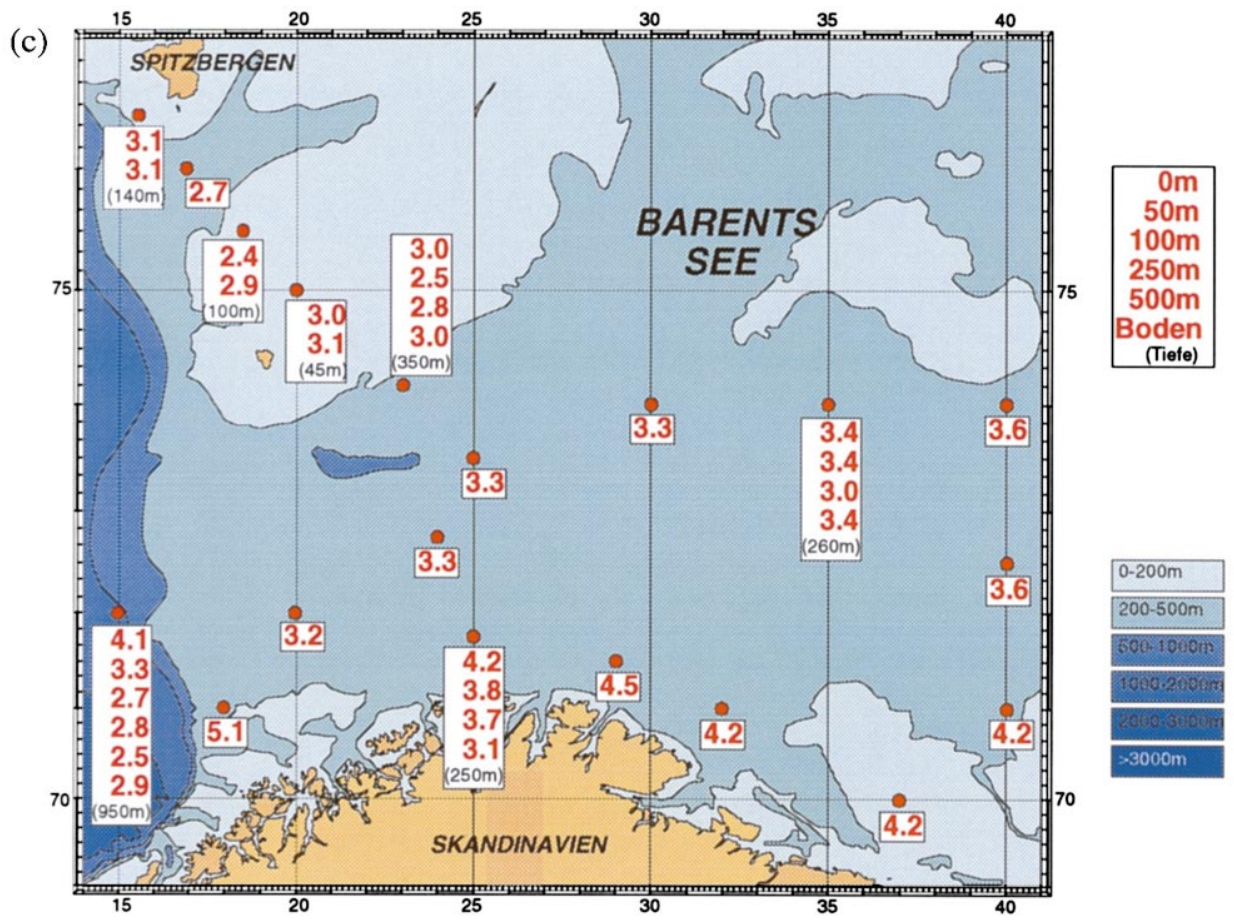

Fig. 1. (a) Concentration of ${ }^{137} \mathrm{Cs}$ in sea water $\left(\mathrm{Bq} / \mathrm{m}^{3}\right)$ in vertical profiles during summer 1995; Cruise $261 \mathrm{R} / \mathrm{V}$ GAUSS (15 June-27 July 1995); Norwegian Sea and northern North Sea. (b) Concentration of ${ }^{137} \mathrm{Cs}$ in sea water $\left(\mathrm{Bq} / \mathrm{m}^{3}\right)$ in vertical profiles during summer 1995; Cruise $261 \mathrm{R} / \mathrm{V}$ GAUSS (15 June-27 July 1995); Greenland Sea. (c) Concentration of ${ }^{137}$ Cs in sea water $\left(\mathrm{Bq} / \mathrm{m}^{3}\right)$ during summer 1995; Cruise $261 \mathrm{R} / \mathrm{V}$ GAUSS (15 June-27 July 1995); Barents Sea.

one order of magnitude lower than the Sellafield effluents. The activity ratios ${ }^{137} \mathrm{Cs} /{ }^{90} \mathrm{Sr}$ from the LaHague discharges were below 0.8 in recent years, mostly only approximately 0.2 .

The levels of ${ }^{137} \mathrm{Cs}$ activity in the entire area where samples were collected during summer 1995 show no indication of the high discharges from Sellafield before 1985. In addition, there is no sign of any widespread contamination from local sources, e.g. dumped wastes in the Arctic shelf seas. The detected levels are significantly lower than those in 1985 published by Wedekind et al. (1997). Samples taken near the wreck of the 'Komsomolets' show no sign of contamination from the reactor: ${ }^{137} \mathrm{Cs}: 0.8 \mathrm{~Bq} / \mathrm{m}^{3}$ in sea water, $\max .15 .8 \mathrm{~Bq} / \mathrm{kg}$ in $0-2-\mathrm{cm}$ sediment.

Generally, the surface sediment samples (0-2 $\mathrm{cm})$ in the north Atlantic taken in 1995 show activities between 3.6 and $15.8 \mathrm{~Bq} / \mathrm{kg}$ (dry wt.) of ${ }^{137} \mathrm{Cs}$, with exceptions near the Norwegian coast (up to $48.7 \mathrm{~Bq} / \mathrm{kg}$ ). It is assumed that this is also due to contamination from earlier Sellafield discharges because this region is along the pathway of contaminated waters transported from this source. In the Barents Sea, activities in surface sediment are very low $(1.5-5.8 \mathrm{~Bq} / \mathrm{kg})$.

Sediments, in particular in deposition areas, are often used as an integrating indicator of environmental pollution. Therefore, a large number of surface sediments were obtained from Russian Institutes and samples were taken during our own expedition in order to analyse them for gamma emitting radionuclides.

The ${ }^{137}$ Cs levels detected in Kara Sea sediments are in the range of $1.0-20.2 \mathrm{~Bq} / \mathrm{kg}(0-3$ $\mathrm{cm})$ (Nies et al., 1997). Higher specific activities near the rivers $O b$ and Yenisei may reflect input of contaminated river sediments as a consequence of releases from Siberian reprocessing plants. ${ }^{60} \mathrm{Co}$ is detected in one sample in the 
estuary of the river Yenisei. This is consistent with other investigations in the $\mathrm{Ob}$ and Yenisei estuaries (Panteleyev et al., 1995). The levels in general are low compared for example, to those in the Irish, North or Baltic Seas (BSH, 1990, 1996; HELCOM, 1995). ${ }^{137}$ Cs levels in sediment $(0-3 \mathrm{~cm})$, detected in 1997 at eight stations during the Russian/German expedition to the Kara Sea (Amderma/Vaygach flaw lead), are in a similar range of $0.3-20.0 \mathrm{~Bq} / \mathrm{kg}$ (Dethleff et al., submitted). The levels detected are in agreement with other measurements from other groups (JNREG, 1996; King et al., 1997; Krosshavn et al., 1998). However, the joint Norwegian Russian expedition took sediment samples in the direct vicinity of dumped objects and found significantly elevated contamination in some of the Novaya Zemlya Bays.

The radioactivity in coastal waters of the Murmansk region was analysed at six stations. The largest part of the Russian nuclear fleet is stationed in the surroundings of Murmansk, in particular many nuclear submarines (Nilsen et al., 1996). Some higher, though not alarming, activities in sediment samples are found in this region: ${ }^{137} \mathrm{Cs}$ up to $37.5 \mathrm{~Bq} / \mathrm{kg},{ }^{60} \mathrm{Co}$ up to $22.7 \mathrm{~Bq} / \mathrm{kg}$ and ${ }^{241} \mathrm{Am}$ in very low amounts (up to $3.1 \mathrm{~Bq} / \mathrm{kg}$ ). According to Rissanen et al. (1998), the elevated ${ }^{60} \mathrm{Co}$ values suggest some small release of radioactivity from nuclear facilities. However, the ${ }^{137} \mathrm{Cs}$ levels of sea water in these areas are in the range from 4.7 to $8.0 \mathrm{~Bq} / \mathrm{m}^{3}$ which are not indicative of a significant contamination. An intensive survey of that region was carried out by Matishov et al. (1998).

\subsection{Numerical modelling}

A hierarchy of three-dimensional coupled ice-ocean circulation models was applied to study the major pathways for radioactive contaminant transport in the Arctic. The circulation models covered three different spatial scales:

- the local scale;

- the regional scale; and

- the global scale.
The models were used to provide essential information on the seasonality of ocean currents, stratification, ice formation and ice transport on all scales. Endpoints were circulation patterns on different time scales that served as source functions for transport modelling of dissolved radioactivity (Harms, 1997b; Nies et al., 1997; Harms et al., 1998).

Parts of the high level radioactive waste, like for example whole submarines, were dumped in small and shallow bays along the east coast of Novaya Semlya. To assess the consequences of damage or leakage for the very near field, we ran a model of Abrosimov Bay (Harms and Povinec, 1998), because here the knowledge of topography and hydrography is most advanced. The model results showed significant variations in the bay circulation due to a pronounced seasonality in wind forcing and ice cover. In general, the radionuclide concentrations in the bay range between 2000 and $3000 \mathrm{~Bq} / \mathrm{m}^{3}$ in seawater, following a hypothetical release of $1 \mathrm{TBq} /$ year. These values would be two or three orders of magnitude higher than recently observed levels in the North Sea.

The regional scale models covered the Arctic shelf regions of the Barents and Kara Seas (Harms, 1997b). Release rate scenarios were performed for a constant release of $1 \mathrm{TBq} /$ year ${ }^{137}$ Cs into Abrosimov Bay. In these scenarios the average concentrations in the central Kara Sea did not exceed $1 \mathrm{~Bq} / \mathrm{m}^{3}$ which would be lower than the existing background level.

Even in a 'worst case scenario' (Fig. 2), which assumes an instantaneous release of the total ${ }^{137}$ Cs activity from all four dump sites (Abrosimov Bay, Stepovoy Bay, Tzivolky Bay, Novaya Semlya Trough total: $1 \mathrm{PBq}$ in 1995), depth-integrated maximum concentrations in the central Kara Sea did not exceed $50 \mathrm{~Bq} / \mathrm{m}^{3}$. This would correspond roughly to already existing levels, e.g. in the North, Baltic or Irish Seas.

In large scale dispersion studies (Nies et al., 1997; Karcher et al., 1998), a $1 \mathrm{TBq}$ /year release of ${ }^{137} \mathrm{Cs}$ was applied to the east coast of Novaya Semlya. The scenario confirmed that the contaminated surface plume leaves the area towards the 


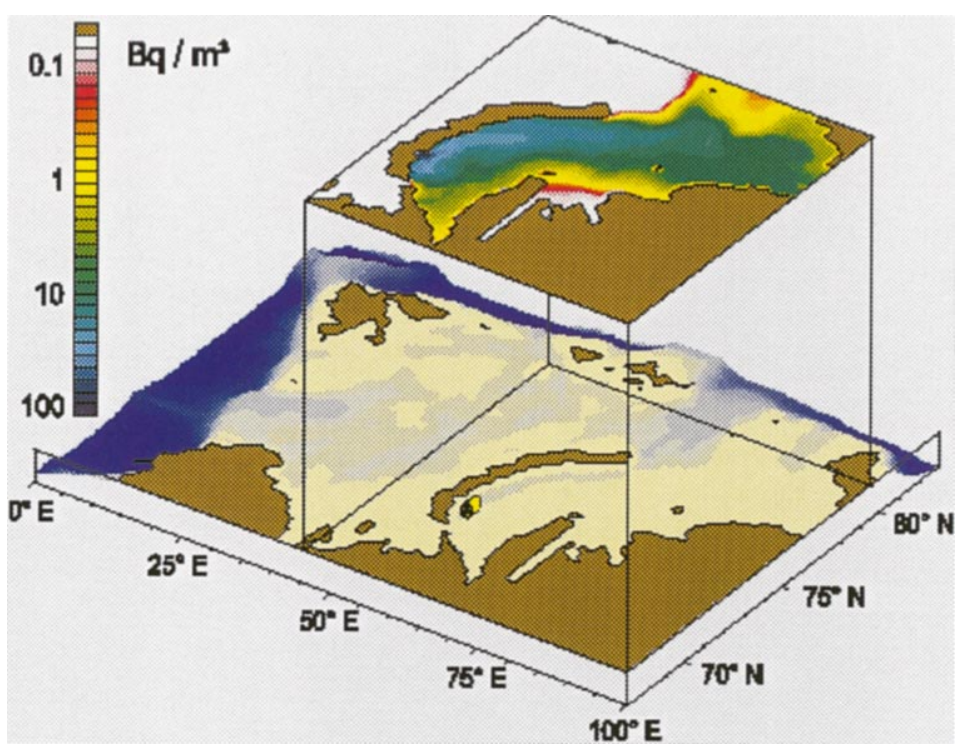

Fig. 2. Simulated concentrations of ${ }^{137} \mathrm{Cs}$ (upper level) in the Kara Sea (lower level: topography with indication of the waste location) following a 'worst case scenario' release from the dump sites. An instantaneous release of $1 \mathrm{PBq}$ was assumed.

north-east, advected by water masses of Atlantic origin and also towards the east with a coastal current into the Laptev Sea (Fig. 3).

In the mixed layer, the contaminants were advected pole-wards until they were picked up by the transpolar driftstream. Fram Strait was reached in approximately 7-8 years and 4 more years were needed to reach the Denmark Strait. Concentration levels decreased from 1 to 0.1 $\mathrm{Bq} / \mathrm{m}^{3}$ in the Kara Sea down to $10^{-2} \mathrm{~Bq} / \mathrm{m}^{3}$ in the East Greenland Current.

On the northern Kara Sea Shelf, significant
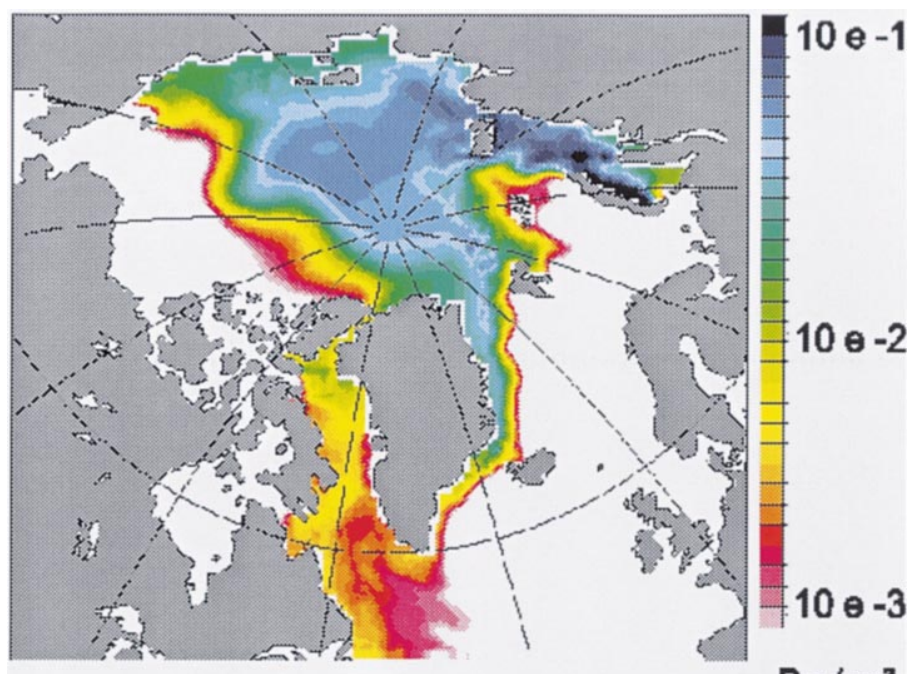

\section{$\mathrm{Ba} / \mathrm{m}^{3}$}

Fig. 3. Simulated surface concentration of ${ }^{137} \mathrm{Cs}$ in the Arctic Ocean and north-east Atlantic after 30 years of dispersion following a continuous release of $1 \mathrm{TBq} /$ year from the dump sites in the Kara Sea. 
parts of contaminants were mixed down to the bottom. The 'intermediate' radioactive tracers reached Fram Strait after approximately 18 years. The 'deep' tracers cross the Lomonosov Rigde to enter the Canadian basin. They reached the Canadian Archipelago after 30 years, however, at very low levels $\left(10^{-2}\right.$ to $\left.10^{-3} \mathrm{~Bq} / \mathrm{m}^{3}\right)$.

Like on the regional scale, the simulated levels of radioactivity were extremely low. Even a simulated (but very unrealistic) 'worst case' showed no significant contamination of the Arctic Ocean. Computed values of $<50 \mathrm{~Bq} / \mathrm{m}^{3}$ would be in the range of existing background values which are mostly influenced by the Sellafield discharge. This became evident when comparing the 'worst case scenario' results with a 'Sellafield hindcast scenario'.

\section{Sediment and radionuclide transport by Kara Sea ice}

Different artificial radionuclides - such as ${ }^{134,137} \mathrm{Cs},{ }^{60} \mathrm{Co}$, and ${ }^{239,240} \mathrm{Pu}$ - tend to attach to suspended particulate matter (SPM) or fine grained surface sediments, which may be incorporated into Arctic sea-ice in shallow, near coastal areas. Meese et al. (1997) and Landa et al. (1998) report enhanced ${ }^{137} \mathrm{Cs}$ contamination in central Arctic sea-ice sediments which might have originated on the shallow Siberian shelves.

Dethleff et al. (submitted) give an estimate of possible ${ }^{137} \mathrm{Cs}$ and ${ }^{239,240} \mathrm{Pu}$ transport attached to particulate inclusions in sea-ice formed in western Kara Sea flaw leads. The authors combine data on sea-ice sediment concentrations and ice production estimates with measured and calculated radionuclide contamination levels in surface deposits and suspended particulate material close to - or directly beyond - the flaw lead sections.

Based on a modeled 'worst case' release scenario of $1 \mathrm{PBq}{ }^{137} \mathrm{Cs}$ and $10 \mathrm{TBq}{ }^{239,240} \mathrm{Pu}$ (entire inventories) from the Novaya Zemlya dumping bays (Harms, 1997b), the maximum entrainment rates of particle-bound ${ }^{137} \mathrm{Cs}$ and ${ }^{239,240} \mathrm{Pu}$ into newly forming lead ice were estimated by Dethleff et al. (submitted) to reach as much as 0.58 and $0.17 \mathrm{TBq}$, respectively. This represents an annual radionuclide dispersal with sea-ice sediments of only $0.0004 \%$ and $1.2 \%$ of the total Kara Sea ${ }^{137} \mathrm{Cs}$ and ${ }^{239,240} \mathrm{Pu}$ inventories.

From general knowledge of sediment entrainment and transport in Arctic sea-ice it can be concluded that despite a low content of particulate matter, Kara Sea ice has a high potential transport capacity for concentrated sediment and attached radioactive contaminants over large distances in extremely short time-periods. Entrainment and transport of particle-bound ${ }^{137} \mathrm{Cs}$ and ${ }^{239,240} \mathrm{Pu}$ in Kara Sea lead-ice may vary significantly depending on:

- the contamination level in the water column and the sediment source on the shelf surface;

- the entrainment process and the behaviour of the radionuclides in the water column after re-suspension; and

- the total amount of contaminated sediment entrained.

\section{Conclusions}

1. No significant radioactive contamination from sources in the Kara Sea was detected by the analyses of water and sediment samples.

2. The concentrations of the most relevant radionuclides in the Barents, Greenland and Kara Seas are lower than those in former times or presently in the North or Baltic Seas.

3. No significant contamination was detected in the area of the sunken Russian nuclear submarine 'Komsomolets'.

4. The transport pattern from contamination from the North Sea by radioactive signals can be traced to Arctic waters.

5. The results of the modelling show no significant pollution even for worst case scenarios of releases from the waste in the Kara Sea to other sea areas in the Arctic or North Atlantic waters.

6. The results from the dispersion models suggest that, even for worst case scenarios, the contamination of Arctic waters and North 
Atlantic areas is relatively minor compared to pre-contamination from the Sellafield source or global fallout in the 1960s. The long-range simulation of the Sellafield discharges of ${ }^{137} \mathrm{Cs}$ since the 1960s is in very good agreement with the measured levels proving that this tool can be used properly for environmental assessments.

7. The transport of contaminated sediments by ice may play a minor role in long-range contamination by radionuclides in the Arctic. However, this transport mechanism might be a rapid short circuit to the North Atlantic Ocean.

\section{Acknowledgements}

This work was supported by the Federal Ministry of Education, Science, Research and Technology and the Federal Ministry of the Environment, Nature Conservation and Nuclear Safety through the Federal Radiation Protection Agency. The views and opinions expressed in this work do not necessarily reflect the opinion of the funding institutions.

\section{References}

Ådlandsvik B, Loeng H. A study of the climatic system in the Barents Sea. Polar Res 1991;1(10).

Baxter MS, Harms IH, Osvath I, Povinec PP, Scott EM. Modelling potential radiological consequences of radionuclide waste dumping in the Kara Sea. J Environ Radioact 1998;39(2):161-181.

BSH. Überwachung des Meeres. Bericht für das Jahr 1988. Hamburg, 1990.

BSH. Überwachung des Meeres. Bericht für das Jahr 1991/92. Hamburg, 1996.

Coachman LK, Barnes CA. The contribution of Bering Sea water to the Arctic Ocean. Arctic 1961;14:147-160.

Dahlgaard H. Sources of ${ }^{137} \mathrm{Cs},{ }^{90} \mathrm{Sr}$ and ${ }^{99} \mathrm{Tc}$ in the East Greenland Current. J Environ Radioact 1994;25:37-55.

Dethleff D, Kleine E, Loewe P. Oceanic heat loss, sea ice formation and sediment dynamics in a turbulent Siberian flaw lead. Proceedings of the summer school of Physics of ice-covered seas, Savonlinna, Finland, Report Series in Geophysics. University of Helsinki, Dept. of Geophysics, 1994;28:35-40.

Dethleff D, Nies H, Harms IH, Karcher MJ. Dispersal of particle-bound and dissolved radionuclides through flaw lead produced sea-ice and dense water in the western Kara Sea. J Mar Systems, submitted.

Eicken H, Reimnitz E, Alexandrov V, Martin T, Kassens H, Viehoff T. Sea-ice processes in the Laptev Sea and their importance for sediment export. Cont Shelf Res 1997;17(2):205-233.

Guegueniat P, Kershaw P, Herrmann J, Bailly du Bois P. New estimation of La Hague contribution to the artificial radioactivity of Norwegian waters (1992-1995) and Barents Sea (1992-1997). Sci Total Environ 1997;202:249-266.

Harms IH. Watermass transformation in the Barents Sea. Application of the HAMburg Shelf Ocean Model (HAMSOM). ICES J Mar Sci 1997a;54:351-365.

Harms IH. Modelling the dispersion of ${ }^{137} \mathrm{Cs}$ and ${ }^{239} \mathrm{Pu}$ released from dumped waste in the Kara Sea. J Mar Systems 1997b;13:1-19.

Harms IH, Karcher MJ. Modelling the seasonal variability of circulation and hydrography in the Kara Sea. JGR-Oceans, 1998:accepted for publication.

Harms IH, Povinec PP. The outflow of radionuclides from Novaya Zemlya Bays - modelling and monitoring strategies. Proceedings of the International Symposium on Marine Pollution. Monaco, 5-9 October 1998.

Harms IH, Karcher MJ, Nies H, Dethleff D. Modelling transport and dispersion of anthropogenic radio-activity in the Arctic Ocean. Proceedings of the International Symposium on Marine Pollution. Monaco, 5-9 October 1998.

HELCOM. Radioactivity in the Baltic Sea 1984-1991. Balt Sea Environ Proc No. 61. Hamburg, 1995.

Herrmann J, Nies H, Goroncy I. Plutonium in the deep layers of the Norwegian and Greenland Seas. Radiation Protection Dosimetry, special issue: Radionuclides in the oceans (RADOC 96-97) Part II: distributions, models and impacts, 7-11 April 1997, Norwich/Lowestoft, UK, 1998.

Høibråten S, Thoresen PE, Haugan A. The sunken nuclear submarine Komsomolets and its effects on the environment. Sci Total Environ 1997;202:67-78.

IAEA. Predicted radionuclide release from marine reactors dumped in the Kara Sea - report of the source team working group of the IASAP, IAEA-TECDOC-938, Vienna, 1997.

JNREG - Joint Norwegian-Russian Expert Group. Dumping of radioactive waste and radioactive contamination in the Kara Sea. In: Strand P, Nikitin AI, Lind B, Salbu B, Christensen GC, editors. Results from 3 years of investigations (1992-1994) in the Kara Sea. NRPA, Østerds, Norway, 1996.

Karcher MJ, Harms IH, Smith JN. Long-range transport of ${ }^{129} \mathrm{I}$ and ${ }^{137} \mathrm{Cs}$ in the Nordic seas and the Arctic Ocean. Proceedings of the International Symposium on Marine Pollution. Monaco, 5-9 October 1998.

Kershaw P, Baxter A. The transfer of reprocessing wastes from north-west Europe to the Arctic. Deep Sea Res 1995;42:1413-1448.

Kershaw P, Gurbutt P, Woodhead D, Leonard K, Rees J. 
Esimates of fluxes of ${ }^{137} \mathrm{Cs}$ in northern waters from recent measurements. Sci Total Environ 1997;202:211-223.

King SE, Carroll J, Johnson DR et al. Transport of caesium in the Kara Sea, radioprotection - colloques, vol. 32, C2: radionuclides in the Oceans (RADOC 96-97) Part I: Inventories, Behaviour and Processes, 7-11 October 1996, Cherbourg-Octeville, France, 1997:231.

Krosshavn M, Carroll J, Engøy T et al. Transport pathways of radionuclides and chemical contaminants in the Kara Sea. Rad. Prot. Dos. Radionuclides in the oceans (RADOC 96-97) Part II: Distributions, Models and impacts, 7-11 April 1997, Norwich/Lowestoft, UK, 1998.

Landa E, Reimnitz E, Beals D, Pochkowski J, Rigor I. Transport of ${ }^{137} \mathrm{Cs}$ and ${ }^{239,240} \mathrm{Pu}$ by ice rafted debris in the Arctic Ocean. Arctic 1998;51(1):27-39.

MacDonald RW, Bewers JM. Contaminants in the Arctic marine environment: priorities for protection. ICES J Mar Sci 1996;53:537-563.

MAFF. Radioactivity in surface and coastal waters of the British Isles, 1994. Aquatic Environ. Monitoring Report No. 45. Dir Fish Res, Lowestoft, UK, 1995.

Matishov GG, Matishov DG, Namjatov AA, Carroll JL, Dahle S. Anthropogenic radionuclides in Kola and Motovsky Bays of the Barents Sea, Russia. J Environ Radioact, 1998.

Meese DA, Reimnitz E, Tucker III WB, Gow AJ, Bischof J, Darby D. Evidence for radionuclide transport by sea-ice. Sci Total Environ 1997;202:267-278.

Nies H, Bahe C, Dethleff D, Harms IH, Karcher MJ, Kleine E. Transport and dispersion of artificial radioactivity in the Arctic Ocean-model studies and observations. Radioprotection - Colloque 1997;32(C2):407-416.

Nilsen T, Kudrik I, Nikitin A. The Russian northern fleet; sources of radioactive contamination, Bellona Rep. vol. 2, Oslo, Norway, 1996.

Nürnberg D, Wollenburg I, Dethleff D et al. Sediments in Arctic sea ice - entrainment, transport and release. Mar Geol 1994;119:185-214.

OSPARCOM (and reports from previous years): Report on liquid discharges from nuclear installations in 1995. Oslo and Paris Commission. London, 1997.

Panteleyev GP, Livingston HD, Sayles FL, Medkova ON. Deposition of plutonium isotopes and Cs-137 in sediments of the $\mathrm{Ob}$ Delta from the beginning of the nuclear age. In:
Strand, Cooke, editors. Environmental radioactivity in the Arctic. Osterås, Norway: NRPA, 1995:57-64.

Pfirman S, Colony R, Nürnberg D, Eicken H, Rigor I. Reconstructing the origin and trajectory of drifting Arctic sea ice. J Geophys Res 1997;102(C6):12575-12586.

Povinec PP, Osvath I, Baxter MS et al. Summary of IAEAMEL's investigation of Kara Sea radioactivity and radiological assessment. Mar Pollut Bull 1997;35(7-12):235-241.

Rissanen K, Ikäheimonen TK, Matishov DG, Matishov GG. Radioactivity levels in Kola Bay. Radiation Protection Dosimetry, special issue: radionuclides in the oceans (RADOC 96-97) Part II: distributions, models and impacts, 7-11 April 1997, Norwich/Lowestoft, UK, 1998

Rudels B, Jones EP, Anderson LG, Kattner G. On the intermediate depth waters of the Arctic Ocean. In: Johannessen OM, Muench RD, Overland JE, editors. The role of the polar oceans in shaping the global climate. Washington, DC: AGU, 1994:33-46.

Rudels B, Anderson LG, Jones EP. Formation and evolution of the surface mixed layer and halocline of the Arctic Ocean. J Geophys Res 1996;101:8807-8821.

Scott EM, Gurbutt P, Harms I et al. Radiological impact assessment within the IAEA Arctic Assessment Project. Rad. Prote. Dosimetry, special issue: Radionuclides in the oceans (RADOC 96-97) Part II: distributions, models and impacts, 7-11 April 1997, Norwich/Lowestoft, UK, 1998

Sjoeblom K-L, Linsley GS. International Arctic Seas Assessment Project (IASAP). Rad. Prot. Dosimetry, special issue: radionuclides in the Oceans (RADOC 96-97) Part II: Distributions, models and impacts, 7-11 April 1997, Norwich/Lowestoft, UK, 1998

UNSCEAR. Ionizing radiation: sources and biological effects. New York: United Nations Scientific Committee on the Effects of Atomic Radiation, 1982.

Wedekind Ch, Gabriel H, Goroncy I, Främcke G, Kautsky H. The distribution of artificial radionuclides in the waters of the Norwegian-Greenland Sea in 1985. J Environ Radioact 1997;35(2):173-201.

Yablokov AV, Karasev BK, Rumyantsev VM et al. 'White Book'. Facts and problems related to radioactive waste disposal in seas adjacent to the territory of the Russian Federation. Office of the President of the Russian Federation, Moscow, 1993. 